\title{
THE INFLUENCE OF THIRD-PARTY FUNDS, NON-PERFORMING LOANS (NPL) ON CREDIT DISTRIBUTION WITH PROFITABILITY AS INTERVENING VARIABLE IN COMMERCIAL BANKS
}

\author{
Sri Hermuningsih, Pristin Prima Sariz, Anisya Dewi Rahmawatiz \\ Universitas Sarjanawiyata Tamansiswa \\ Email : hermun_feust@yahoo.co.idl; pristin.primas@gmail.com2; anisyadewil6@gmail.com3
}

\begin{abstract}
:
Banks are financial institutions that collect and distribute funds in the forms of deposits such as savings, deposits, current accounts, etc. from and for people who need funds for various needs, such as for consumption, working capital or business capital, housing and investment. In addition, banks must help the community to improve their living standards by distributing funds or giving credit to people who need funds. This is in accordance with the function of the bank itself, namely the bank as the distributor of funds. The purpose of this research is to examine and obtain evidence about factors that influence loan distribution at a bank. Internal factors that influence loan distribution are Third Party Funds, Non-Performing Loans, and Profitability. Efforts to increase credit at banks require optimal efforts to raise third-party funds, good credit management, and capital strengthening. This type of research is quantitative research with purposive sampling technique. The population used in this study is commercial banks from 2013 to 2017. The data come from commercial bank financial statements. As the benefit of this research the government can use it as a mapping material for distributing loan to commercial banks; the bank management can take it into consideration in making commercial bank lending policies. The results of the research show that profitability can mediate the relationship between third party funds and nonperforming loans on loan distribution. Third party funds have a significant positive effect on loan distribution. Non-Performing Loans have a significant negative effect on loan distribution.
\end{abstract}

Keywords: $\quad$ Loan Distribution, Third Party Funds, Non-Performing Loans, And Profitability

\section{Introduction}

In a country's economy, especially Indonesia today, financial institutions have many functions that are so important and strategic. A bank is considered as the largest financial institution that is able to collect funds from third parties and distribute them to the people who need them so that they can provide great benefits to the community. The funds from the community are called Third-Party Funds and are distributed back to the people who need funds in the form of credit. Credit given to the community is expected to improve the financial welfare of the community, which in turn can strengthen economic growth. Although credit plays a very important role in economic development, in its implementation, funds from the public are not distributed optimally by banks, so it is not in accordance with the stipulated provisions. Third-Party Funds or deposits are funds that have been collected from the community in the form of savings, deposits and current accounts and are the main sources of bank funds. Credit as the largest asset has a fairly high level of risk. The potential risk for credit is the appearance of bad credit or NonPerforming Loan. The NPL ratio is not only an influencing major part to the soundness rating of banks, but it is also an important part of bank management in considering steps to expand credit. The greater the NPL, the bank cannot function as a good intermediary. In other words, the 
International Journal of Economics, Business and Accounting Research (IJEBAR)

Peer Reviewed - International Journal

Vol-4, Issue-2, 2020 (IJEBAR)

E-ISSN: 2614-1280 P-ISSN 2622-4771

https://jurnal.stie-aas.ac.id/index.php/IJEBAR

greater the amount of NPL at banks, the bank performance is poor. Meanwhile, according to Amelia (2017) NPL is 1 (one) indicator of bank health and asset quality. High NPL value can result in a fund or money distributed through credit which will be reduced. This results in a bank having to form an even bigger reserve. High number of NPL can influence bank policies in distributed credit, that is, banks will distribute credit strictly. Kasmir (2014) stated that in order to avoid disbursed loans, there are two important elements in releasing credit, namely: the level of profitability and the level of risk. Ningsih and Utami (2020) show that operating leverage and capital structure influence ROA. The level of profit is the amount of profit determined to be obtained from lending in a period, while the level of risk is the level of risk that will be faced against the possibility of decreasing bank profits from credit activities. The level of profit is determined, among others, by the value of return on assets, which is the ratio of earnings before tax with the average of assets. The greater the value of ROA, the profitability of the bank in question tends to be good/high. This research objective is to determine the factors that influence the amount of credit in commercial banks. The benefit of this research is that the bank can obtain information to control credit to the public so that the credit given generates profitability, for mapping by the government about bank credit for the public and the influencing factors and for reference material in producing reference sources relating to bank credit.

\section{Hypotheses Development}

Banks are financial institutions whose activities are raising funds and providing credit or loan funds to the public. Banks include financing institutions. Banks also offer non-financial services such as safe deposit boxes, money transfers, foreign exchange and so on. The data used are commercial banks in Indonesia. Meanwhile, according to the Sultan and Siswanto, a bank is a bank that operates not only on interest. The three functions of a bank are as follows:

a) a bank for collecting money or public funds.

b) a bank for distributing funds to the public.

c) a bank as trading and money circulation transactions.

\section{Fund Resource}

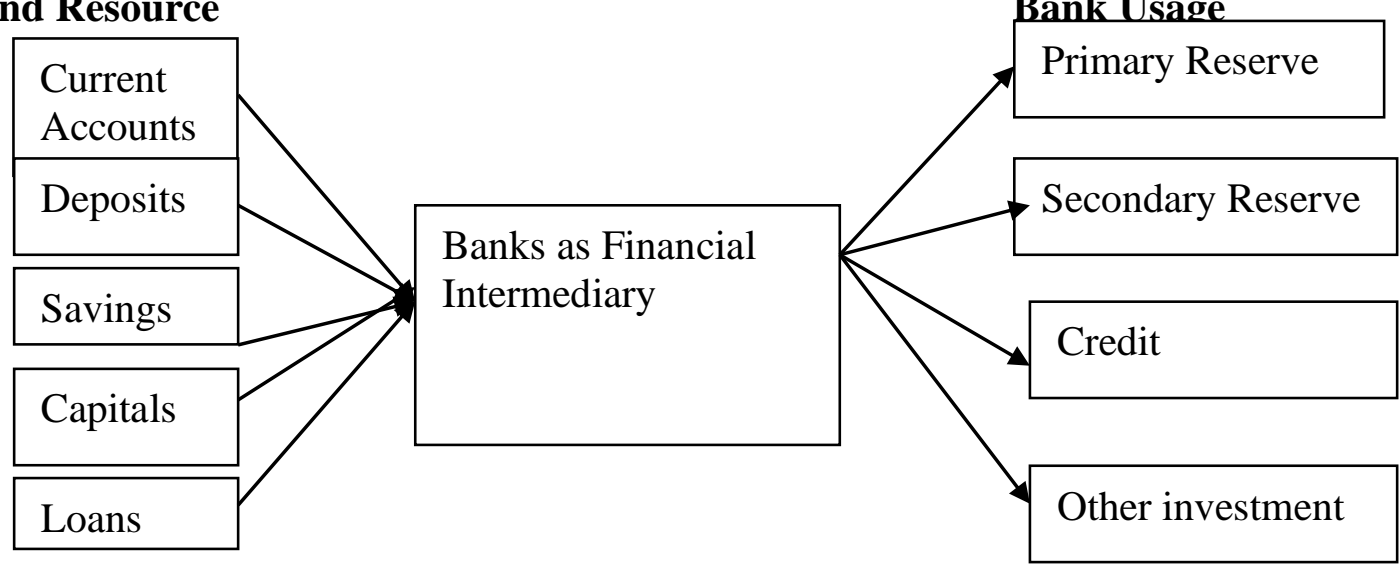

Figure.1 Banks as Financial Intermediary (Resource: Kuncoro dan Suhardjo (2002))

Bank loans or credit are the most important activities of banks in generating profits, but the greatest risk in banks also comes from the provision of credit. According to the Law contained in Article 1 Paragraph 11 of Law No.10 / 1998 concerning banking, credit is a supply of loan 


\author{
International Journal of Economics, Business and Accounting Research (IJEBAR) \\ Peer Reviewed - International Journal \\ Vol-4, Issue-2, 2020 (IJEBAR) \\ E-ISSN: 2614-1280 P-ISSN 2622-4771 \\ https://jurnal.stie-aas.ac.id/index.php/JJEBAR
}

facilities and money, which is based on agreements between the two parties to repay the debt at a certain time period and at the same time pay the interest. This credit risk is related to internal and external factors. Meanwhile, according to Susilo et al (2000) in Roheni, (2012) one of the main activities of financial institutions including banks is distributing funds to the public. The very first receipt in a tub is credit distribution. Credit distribution is classified as a productive asset and the level of income is high, so there is a consequence of credit distribution that has a relatively higher risk than the other assets. Significant factors affecting credit are third party funds, Non Performing Loans and Profitability (Romli \& Alie, 2017). Capital adequacy, risk premium, and liquidity increase the number of loans to the private sector. Interest rates and the amount of reserves tend to reduce the number of loans. Inflation can reduce the amount of lending to the private sector (Akinlo \& Oni, 2015). Bank capitalization can increase credit growth (Tan, 2014). Specific bank characteristics such as deposit growth and profitability can increase credit growth both before and after the financial crisis (Allen,et. al 2010).

The strategy for distributing bank credit applies the principle of five $\mathrm{C}(5 \mathrm{C})$.

The principle is as follows:

a) Collateral is knowing the amount of collateral value (collateral) from the debtor.

b) Capital (Capital) is measuring the ability of own capital from the debtor.

c) Customer capacity (Capacity) is measuring the ability of the debtor's business such as management, marketing, HR and financial aspects.

d) Customer condition is measuring the prospect of the future business cycle of the debtor.

e) Character is measuring the willingness to pay from the debtor before and during the loan application such as the debtor's promises.

Types of bank credit include the following:

a) Working Capital Loan

Working capital loans are loans to finance working capital for community businesses.

b) Investment Credit

Investment credits are loans to finance investment or expansion of corporate or individual

businesses

c) Consumer Credit

Consumption credits are loans to finance community consumption needs such as vehicles, children's education, and cars.

d) Small Business Credit

Small business loans are loans for financing for small businesses.

Third-party funds represent funds or money originating from customers or residents who invest in several programs, namely deposits, current accounts, and time savings. In addition, according to Kuncoro, M., (2002) Third-Party Funds (DPK) are originally derived from business entities, communities, and individuals who use a variety of savings products. Meanwhile, according to Oktaviani (2012) Third-party funds (DPK) are the largest source of funds for banks to carry out their operations to distribute credit.

Bank funds obtained from the public are the largest funds for a bank reaching $80 \%-90 \%$. Savings funds at banks are also utilized by banks for their operational activities (Ratu Mashita Gumilarty \& Indriani, 2017). There are several types of banking fund sources: (1) Funds sourced 


\section{International Journal of Economics, Business and Accounting Research (IJEBAR) \\ Peer Reviewed - International Journal \\ Vol-4, Issue-2, 2020 (IJEBAR) \\ E-ISSN: 2614-1280 P-ISSN 2622-4771 \\ https://jurnal.stie-aas.ac.id/index.php/IJEBAR}

by the bank itself, (2) funds from the community and (3) funds obtained from other institutions. Further, it is explained that among the three sources of funds, funds obtained from the community are easier to obtain and are widely available in the community. Funds from this community are known as Third Party Funds, which are obtained from the community in the form of deposits(Kasmir, 2014). Third-Party Funds (DPK) consist of time deposits (deposits), savings and current accounts. Third-Party Funds (DPK) also comes from non-financial corporations, individuals and others.

Types of third-party funds include:

1. Saving

Savings are customers' deposits who deposit or withdraw upon certain conditions that apply to each bank. In addition, according to the Law of the Republic of Indonesia Number 10 of 1998 concerning Banking, the definition of savings is a deposit whose withdrawal can only be used according to certain conditions which have been agreed from the beginning, but cannot be used to withdraw checks, current account, and other tools with the similar function.

2. Current account

Current accounts represent third-party deposits or savings at a bank with withdrawals can be used at any time by using checks and warrants on other payments or by book transferring.

3. Deposit

Deposits are timed deposits issued by banks with withdrawals can only be made within a certain time period in accordance with prior agreement (Kuncoro, M., 2002).

These funds are the most important funding for a banking activity because they support operational activities as well as a measurement of bank cleanliness if the bank can finance operations at this source. This also indicates a very high level of community trust.

Non Performing Loans are measures of the ability to repay credits by debtors. Greater NPL reflects greater inability of the debtor to repay debts and interest from the banks. NPL reflects the bank's risk in distributing credit, the smaller NPL at a bank is, the smaller the credit risk experienced by banks is. NPL is an indicator of a bad bank credit where the customer or debtor is unable to pay part or all of the loan principal and interest. Credits with problems according to the provisions of BI (Bank Indonesia) are credits that are grouped in the collections of Sub-standard (KL), Doubtful (D), and Loss (M). Solid NPL is calculated through a comparison between the number of credits in problem compared to the total credits. According to Dzulfikar, (2017) NPL is a condition when customers are unable to pay part or all of their obligations to a bank as agreed at the beginning of the agreement. This risk is very influential in bank operations. Nonperforming loans can be interpreted as follows: "Non-performing loans are loans that have difficulty in repayment due to intentional factors and / or due to external factors beyond the ability of the debtor's control, such as poor economic conditions"(Dahlan, 2005). Nonperforming loans represent risks to credit repayment, especially to parties who have been expected to make payments but are not willing to pay. On the other hand, non-performing loans occur due to the failure of repayment on the agreement so that the delay in the receipt is of the potential loss. Every bank must have experienced bad credit, in other words, customers cannot pay off or pay their credit. There are two (2) factors that cause bad credit facilities, among others, the bank's credit analysist is not observant nor careful in checking documents and not careful in calculating banking ratios. 
International Journal of Economics, Business and Accounting Research (IJEBAR)

Peer Reviewed - International Journal

Vol-4, Issue-2, 2020 (IJEBAR)

E-ISSN: 2614-1280 P-ISSN 2622-4771

https://jurnal.stie-aas.ac.id/index.php/IJEBAR

NPL reflect the quality of bank credit. Banks with high NPL have low bank credit quality. Credit quality is classified into five parts: Current (L), Special attention, Substandard, Noncurrent, Doubtful and Loss. According to Bank Indonesia Circular No.7 / 3 / DPNP dated January 31, 2005 there are 3 measurements of credit quality criteria: business prospects, performance and debtors' ability to pay.

Table 1. Credit Quality Classification

\begin{tabular}{|c|c|c|c|c|c|}
\hline Components & Current & Substandard & $\begin{array}{l}\text { Special } \\
\text { mention }\end{array}$ & Doubt & Loss \\
\hline $\begin{array}{l}\text { Business } \\
\text { prospective }\end{array}$ & $\begin{array}{l}\text { Good business } \\
\text { growth }\end{array}$ & $\begin{array}{l}\text { Limited } \\
\text { growth }\end{array}$ & $\begin{array}{l}\text { Does not } \\
\text { grow }\end{array}$ & $\begin{array}{l}\text { Business } \\
\text { decreased }\end{array}$ & $\begin{array}{l}\text { - Persistence is } \\
\text { doubtful and } \\
\text { difficult to } \\
\text { recover } \\
\text { - the possibility } \\
\text { of business } \\
\text { stalled }\end{array}$ \\
\hline $\begin{array}{l}\text { Performance } \\
\text { (Profit } \\
\text { revenew) }\end{array}$ & $\begin{array}{l}\text { High and stable } \\
\text { profit }\end{array}$ & $\begin{array}{l}\text { Profit is } \\
\text { quite good } \\
\text { but has the } \\
\text { potential to } \\
\text { decline }\end{array}$ & Low profit & $\begin{array}{l}\text { - Very small } \\
\text { / negative } \\
\text { earnings } \\
\text {-Operational } \\
\text { losses are } \\
\text { financed by } \\
\text { asset sales }\end{array}$ & $\begin{array}{l}\text {-Large loss } \\
\text {-Inability to pay } \\
\text { obligations } \\
\text { - effort cannot } \\
\text { be sustained }\end{array}$ \\
\hline $\begin{array}{l}\text { Debtor Ability } \\
\text { (Accuracy in } \\
\text { paying } \\
\text { principal and } \\
\text { interest) }\end{array}$ & $\begin{array}{l}\text { Timely payment, } \\
\text { no arrears, } \\
\text { according to } \\
\text { credit terms }\end{array}$ & $\begin{array}{ll}\text { Interest } & \\
\text { principal } & \\
\text { arrears for } & \text { for } \\
\text { up to } 90 \\
\text { days }\end{array}$ & $\begin{array}{l}\text { Interest } \\
\text { arrears up } \\
\text { to } 120 \\
\text { days }\end{array}$ & $\begin{array}{l}\text { Principal and } \\
\text { interest } \\
\text { arrears for up } \\
\text { to } 180 \text { days }\end{array}$ & $\begin{array}{l}\text { Principal / } \\
\text { interest arrears } \\
\text { up to } 180 \text { days }\end{array}$ \\
\hline
\end{tabular}

Based on the above factors the bank will review in more detail. That is the beginning of a bank's business taking into account the problems in its business growth, market situation, and conditions and management. Therefore, the debtor does this to protect the environment. From the debtor's performance, a bank analyzes the profitability, capital structure, cash flow, then sensitivity will have an impact on market risk.

While from the ability to pay a bank will see the accuracy of the principal and interest payments, the availability and accuracy of debtor financial information, the completeness of credit documentation, compliance with credit agreements, the appropriateness of the funds use, to the reasonableness of the payment obligation source.

Strategies to improve credit quality using the $3 \mathrm{R}$ principles are as follows:

a) Rescheduling is a change in credit terms such as a payment schedule or time period and changes in the installment amount.

b) Reconditioning is unlimited credit conditions such as changes in interest rates / penalties.

c) Restructuring or realignment is a change in credit terms such as changes in types of credit facilities, conversion of interest arrears to new loan principal. 
International Journal of Economics, Business and Accounting Research (IJEBAR)

Peer Reviewed - International Journal

Vol-4, Issue-2, 2020 (IJEBAR)

E-ISSN: 2614-1280 P-ISSN 2622-4771

https://jurnal.stie-aas.ac.id/index.php/IJEBAR

Profitability is the level of bank profitability. Profitability is the performance of a company to obtain profits within a certain time. The profitability ratio aims to see the performance of the bank to get profit in a certain time. The greater the profitability ratio at the company, then the more the bank has succeeded in increasing revenue and minimizing operational costs incurred. Profitability analysis can be used to assess the performance of a company which is actually a profit motive (Dewi, 2017). Profitability can be calculated by using the Return On Assets (ROA) ratio. ROA is a comparison between net income and average assets. It is a ratio that measures a company's ability to use all assets owned to generate profits after tax. Profit is the main goal of a company or banking. The purpose of achieving bank profits is the adequacy of fulfilling obligations to shareholders, evaluating the performance of leaders, and increasing the attractiveness of investors to buy shares. High bank profits can encourage trust in society. When banks are able to raise funds or a lot of capital, then banks get wider opportunities to lend (Simorangkir, 2004). The level of profit or profitability at the bank can be measured using return on assets.

Profitability is used as recording of financial transactions which are valued by investors and creditors (banks) as the value of the investment profit amount to be received by investors and the corporate profits amount to assess the performance of the company in paying its debts to creditors on the basis of the asset use level and other resources, then it shows the level of company efficiency. The effectiveness and efficiency of management can be seen from the profits generated against the company's sales and investments as seen from the elements of the financial statements. The higher the value of the ratio is, the better the condition of the company based on profitability ratios will become. High value symbolizes the level of profit and high company efficiency which can be seen from the level of income and cash flow. Profitability is more important than the previous timeframe and the competitor achievement ratio. Thus, an analysis of industry trends is needed to draw useful conclusions about a company's profitability. Profitability ratios reveal the final results of all financial policies and operational decisions made by the management of a company in which it is also influenced by the petty cash recording system.

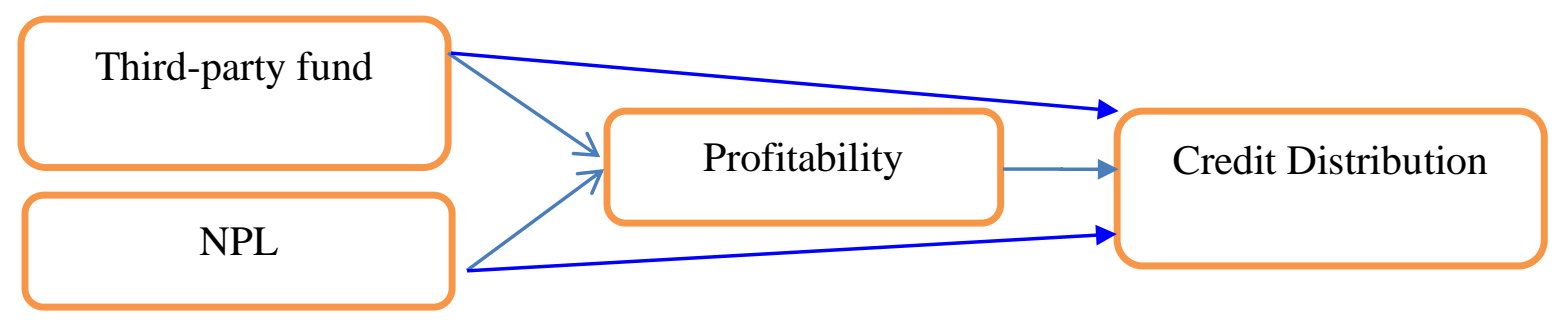

Figure. 2: Theoretical Framework

Resource : Romli \& Alie (2017) and Allen et al (2010)

\section{Research Method}

The study collected data on financial statements and information about government commercial banks. The research subjects were BRI, BNI, Mandiri, BTN, Muamalat and BCA from the years of 2013 to 2017. 
International Journal of Economics, Business and Accounting Research (IJEBAR)

Peer Reviewed - International Journal

Vol-4, Issue-2, 2020 (IJEBAR)

E-ISSN: 2614-1280 P-ISSN 2622-4771

https://jurnal.stie-aas.ac.id/index.php/IJEBAR

Sampling in this study was carried out by using purposive sampling method. Purposive sampling method is a technique for determining samples based on certain considerations with the aim of getting sample units having the desired characteristics and criteria (Ghozali, 2006). The sample criteria in this study were commercial banks and having third-party fund reports during the period 2013-2017; there were 6 commercial banks. The secondary data were in the form of third-party funds, Non-performing loans (NPL), credit distribution and profitability using ROA. They published complete financial statements.

Data sources used in this study were the annual financial statements of a company contained in the Financial Services Authority, reports on scientific research results, scientific research journals, taken from each bank websites and www.idx.co.id

The variables in this study were two independent variables, 1 (one) intervening variable and 1 (one) dependent variables. The independent variables are third-party funds X1, Non performing loans (NPL) X2, Y1 Profitability and Y2 Credit chanelling.

Data management in this study would be processed using the Smartpls 3.0 program. Descriptive statistical tests were applied to determine the effect of third-party funds and Nonperforming loan (NPL) and Credit Distributionas intervening variables on Prositability (ROA) at Government Commercial Banks.

The classic assumption test is a test used to find out whether the multiple regression model used in a study meets the classic assumptions or not. The classic assumptions testspplied are: normality test, multicollinearity test, heteroscedasticity test and autocorrelation test.

The study conducted path analysis. Path analysis is a developed technique of multiple linear regression that is used to analyze the pattern of relationships between variables with the aim at knowing the direct or indirect relationship. The mathematical model of the path model is often called structural model.

The empirical model is as follows:

$\mathrm{Y}_{\text {Credit }}=\alpha+\beta \mathrm{DPK}+\beta \mathrm{NPL}+\beta \mathrm{ROA}+\mathrm{e}$

$\mathrm{Y} 2 \mathrm{ROA}=\alpha+\beta \mathrm{DPK}+\beta \mathrm{NPL}+\mathrm{e}$

Where:

Y1 Credit $=$ Dependent Variable of Credit Distribution,

Y2 ROA = Second dependent variables of profitabilities with proxies Return On Asset (ROA),

DPK $=$ Third-party fund,

NPL $=$ Non Performing Loan

$\mathrm{E}=$ error or level of error .

\section{Results and Discussion}

\subsection{Results}

Table 2. Descriptive Statistics

\begin{tabular}{lllllllc}
\hline & Mean & Median & Min & Max & Std.Dev & Excess Kurtosis & Skewness \\
\hline ROA & 2,51 & 2,7 & 0,08 & 5,03 & 1,378 & $-1,024$ & $-0,269$ \\
NPL & 2,152 & 2,1 & 0,2 & 4,85 & 1,179 & 0,059 & 0,293 \\
Kredit & 12,166 & 12,695 & 10,25 & 13,645 & 1,163 & $-1,405$ & $-0,508$ \\
DPK & 12,349 & 12,923 & 10,64 & 13,758 & 1,109 & $-1,549$ & $-0,418$ \\
\hline
\end{tabular}

International Journal of Economics, Business and Accounting Research (IJEBAR)

Page 46 
International Journal of Economics, Business and Accounting Research (IJEBAR)

Peer Reviewed - International Journal

Vol-4, Issue-2, 2020 (IJEBAR)

E-ISSN: 2614-1280 P-ISSN 2622-4771

https://jurnal.stie-aas.ac.id/index.php/IJEBAR

Resource: data modified, 2019

Table 2 shows that the number of observations was 42 observations with a total sample of 7 commercial banks in 2013-2018. ROA's commercial bank was at minimum of $0.08 \%$ and an average value of $2.51 \%$. Commercial bank NPL was at minimum of $0.2 \%$ and an average value of 2.152. The variable value of commercial bank credit was at minimum of 10.25 and an average value of 12.166. Commercial banks' Third Party Funds (DPK) was at minimum value of 10.64 and an average value of 12,349.

1. Table 3. Total Effects

\begin{tabular}{llllll}
\hline & $\begin{array}{l}\text { Original } \\
\text { Sample }\end{array}$ & $\begin{array}{l}\text { Sample } \\
\text { Mean }\end{array}$ & $\begin{array}{l}\text { Standard } \\
\text { Deviasi }\end{array}$ & $\begin{array}{l}\text { T } \\
\text { Statistic }\end{array}$ & P Value \\
\hline DPK -> Kredit & 0,995 & 0,996 & 0,010 & 96,868 & $0,000^{* * *}$ \\
DPK -> ROA & 0,761 & 0,768 & 0,063 & 12,114 & $0,000^{* * *}$ \\
NPL -> Kredit & 0,006 & 0,007 & 0,023 & 0,269 & 0,788 \\
NPL -> ROA & $-0,225$ & $-0,223$ & 0,0947 & 2,330 & $0,000^{* * *}$ \\
ROA -> Kredit & $-0,142$ & $-0,140$ & 0,039 & 3,646 & $0,000^{* * *}$ \\
\hline
\end{tabular}

Resource: data modified, 2019

Note : * $\mathbf{p}<0,1, * * \mathbf{p}<0,05, * * * \mathbf{p}<0,01$

Table 3 shows the total effect of the research variables. Deposits variable had a significant positive effect on credit distribution (Sig Value 0,000 and t 96,868). The number of deposits was increasing so it increased bank lending. DPK variable had a significant positive effect on ROA (Sig 0.000 and t12,114). The number of deposits increased, so it increased the profitability of the commercial banks. The NPL variable had no significant effect on credit distribution (sig value 0.788 and t 0.269 ). NPL variable had a significant negative effect on ROA (sig values 0,000 and $\mathrm{t} 2,330$ ). NPL or bad credit could reduce profitability generated by the commercial banks. ROA variable had a significant negative effect on credit distribution (sig 0,000 and $t-0,142$ ). Banks having a large amount of profitability distributed the low amount of credit. This was because banks taking large profits, so people were reluctant to take credit from the bank.

Table 4. Indirect Effect

\begin{tabular}{llllll}
\hline & $\begin{array}{l}\text { Original } \\
\text { Sampel }\end{array}$ & $\begin{array}{l}\text { Sample } \\
\text { Mean }\end{array}$ & $\begin{array}{l}\text { Standard } \\
\text { Deviation }\end{array}$ & T Statistics & P Value \\
\hline DPK -> ROA -> Kredit & $-0,108$ & $-0,108$ & 0,035 & 3,080 & $0,002^{* *}$ \\
NPL -> ROA-> Kredit & 0,032 & 0,029 & 0,012 & 2,626 & $0,009^{* *}$ \\
\hline
\end{tabular}

Resource: data modified, 2019

NOTE: * $\mathbf{p}<0,1 ; * * \mathbf{p}<0,05 ; * * * \mathbf{p}<0,01$

Table 4 shows that the indirect effect of third-party fund on credit distribution is significantly negative (significance value of 0.002 and coefficient value of -0.108). The number 
International Journal of Economics, Business and Accounting Research (IJEBAR)

Peer Reviewed - International Journal

Vol-4, Issue-2, 2020 (IJEBAR)

E-ISSN: 2614-1280 P-ISSN 2622-4771

https://jurnal.stie-aas.ac.id/index.php/IJEBAR

of third-party fund was not followed by an increase in the number of credit distribution by obtaining bank profitability. The commercial banks as the samples of the study showed that the number of deposits was not followed by the amount of credit distribution by banks having high profitability. So, ROA can mediate the influence of third-party fund on commercial banks lending.

The indirect effect of NPL on credit distribution was significantly positive (significance value of 0.009 and coefficient value of 0.032 ). The number of bad credits owned by banks could increase the amount of credit distribution by having a high amount of bank profitability. So that profitability (ROA) could mediate the effect of NPL on credit distribution.

\begin{tabular}{ll}
\multicolumn{2}{c}{ Tabel 5. R Square } \\
\hline & R Square \\
\hline Kredit & 0,988 \\
ROA & 0,749
\end{tabular}

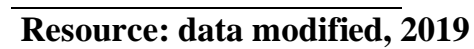

Table 5 shows that $\mathrm{R}$ Square of credit distribution was at 0.988 . This means that the independent variables (third-party fund and NPL) could affect credit distribution by $98.8 \%$ and 0.002 as they were influenced by other variables outside the model. R Square value of ROA variable was 0.749 which indicated that third-party fund and NPL variables could affect ROA by $74.9 \%$ and the remaining $25.1 \%$ was influenced by other variables outside the research model.

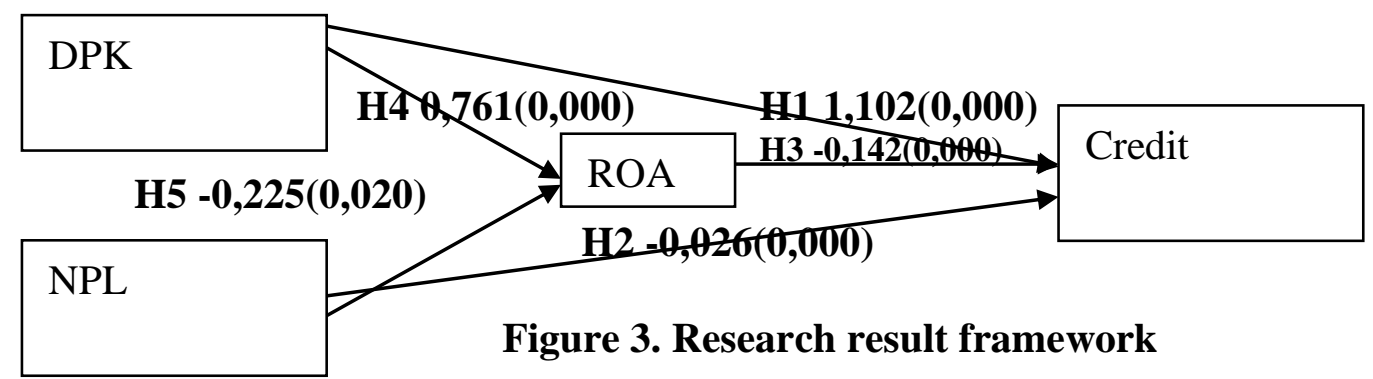

Figure 3 explains that the indirect effect of third-party fund and NPL variables on credit was due to the role of ROA mediation. The results show that the profitability variable (ROA) could mediate a significant positive effect of DPK and NPL on bank credit. The amount of profit obtained by banks could increase the growth of deposits on credit. Likewise, the number of ROA had a significant effect in reducing the amount of credit due to non-performing loans (NPL). With the existence of bad loans (NPL), bank profitability was also reduced, causing credit distribution to decline. In addition, third-party funds also had a direct positive effect on bank credit. NPL had a significant negative direct effect on bank credit.

\section{Conclusion}

The study shows that the profitability with proxy ROA could mediate a significant positive effect of DPK and NPL on bank credit. The higher of profitability the higher of DPK and credit bank. The lower of non performing loan the higher of profitability and credit distribution. In addition, 
International Journal of Economics, Business and Accounting Research (IJEBAR)

Peer Reviewed - International Journal

Vol-4, Issue-2, 2020 (IJEBAR)

E-ISSN: 2614-1280 P-ISSN 2622-4771

https://jurnal.stie-aas.ac.id/index.php/IJEBAR

third-party funds also had a direct positive effect on bank credit. The higher of DPK means that bank credit increase. NPL had a significant negative direct effect on bank credit. The amount of NPL create credit distribution decline.

\section{Limitation and suggestions}

There are some policy implications derived from the findings. Banks can pay attention to the banks' non-performing loan in order to obtain profitability so that they can distribute credit to the public. Banks can improve funding policies so that profitability and bank credit increase. In addition, future researchers can add another variable, namely: CAR, so that the research results are more complete and the time limit can be added.

\section{References}

Akinlo, A. E., \& Oni, I. O. (2015). Determinants of bank credit growth in Nigeria 1980-2010. European Journal of Sustainable Development, 4(1), 23-30. https://doi.org/10.14207/ejsd.2015.v4n1p23

Allen, F., Hryckiewicz, A., Kowalewski, O., \& Tumer-Alkan, G. (2010). Transmission of Bank Liquidity Shocks in Loan and Deposit Markets: The Role of Interbank Borrowing and Market Monitoring. Ssrn. https://doi.org/10.2139/ssrn.1707591

Amelia, \& M. (2017). Analisis Pengaruh Dpk, Ldr, Npl Dan Car Terhadap Jumlah Penyaluran Kredit Pada Pt. Bank Qnb Indonesia, Tbk Periode 2005 - 2014. Jurnal Ekonomi Bisnis, 22(1), 66-74.

Budisantoso. (2017). Bank dan Lembaga Keuangan Lain. Edisi 3. Jakarta : Salemba Empat.

Dahlan, S. (2005). Lembaga Keuangan: Kebijakan Moneter dan Perbankan. Jakarta: Salemba Empat.

Dewi, S. (2017). Pengaruh Profitabilitas, Ukuran Perusahaan, dan Pertumbuhan Asset Terhadap Struktur Modal Dan Nilai Perusahaan. E-Jurnal Manajemen Unud, 6(4), 2222-2252.

Dzulfikar. (2017). Pengaruh Capital Adequacy Ratio, Return On Asset, Operations Expenses/Operations Incomes, Dan Non Performing Loan Terhadap Penyaluran Kredit Bank Campuran Tahun 2009-2013. Jurnal Manajemen Dan Bisnis (Almana), 1(1), 1-10.

Ghozali, I. (2006). Aplikasi Analisis Multivariate Dengan Program SPSS. Cetakan Keempat. Semarang : Bandan Penerbit Universitas Diponegoro.

Kasmir. (2014). Analisis Laporan Keuangan. Edisi Pertama, Cetakan Ketujuh. Jakarta: PT. Rajagrafindo Persada.

Kuncoro, M., \& S. (2002). Manajemen Perbankan : Terori dan Aplikasi. Yogyakarta.

Ningsih, S., \& Utami, W. B. (2020). Pengaruh Operating Leverage dan Struktur Modal terhadap Kinerja Keuangan pada Perusahaan Go Publik Sektor Property Dan Real Estate. Jurnal Akuntansi dan Pajak, 20(2), 154-160.

Oktaviani, P. I. \&. (2012). Pengaruh DPK, ROA, CAR, dan Jumlah SBI Terhadap Penyaluran Kredit Perbankan( Studi Pada Bank Umum Go Public di Indonesia Periode 2008-2011 ). Diponegoro Journal Of Management, 1(2011), 1-9.

Ratu Mashita Gumilarty, G., \& Indriani, A. (2017). Analisis Pengaruh DPK, NPF, ROA, Penempatan Dana Pada SBIS, Dan Tingkat Bagi Hasil Terhadap Pembiayaan Bagi Hasil (Vol. 5).

Roheni, M. (2012). Pengaruh Rasio Kecukupan Modal dan Kredit Macet Terhadap Penyaluran 
International Journal of Economics, Business and Accounting Research (IJEBAR)

Peer Reviewed - International Journal

Vol-4, Issue-2, 2020 (IJEBAR)

E-ISSN: 2614-1280 P-ISSN 2622-4771

https://jurnal.stie-aas.ac.id/index.php/IJEBAR

Kredit. Fakultas Ekonomi Universitas Komputer Indonesia, (112), 1-26.

Romli, H., \& Alie, M. (2017). Diterminan Penyaluran Kredit dan Implikasinya Terhadap Kinerja Profitabilitas Bank yang Terdaftar di Bursa Efek Indonesia Periode 2010-2014. Jurnal Manajemen Dan Bisnis Sriwijaya, 15(1).

Simorangkir. (2004). Pengantar Lembaga Keuangan Bank dan Non Bank. Jakarta: Salemba Empat.

Tan, T. B. P. (2014). Determinants of Credit Growth and Interest Margins in the Philippines and Asia. IMF Working Papers, 12(123), 1. https://doi.org/10.5089/9781475503524.001 